\title{
Promoting a Culturally Adapted Policy to Deal with the COVID-19 Crisis in the Haredi Population in Israel
}

\author{
Hanni Schroeder ${ }^{1,2}$ (D) $\cdot$ Ronny Numa ${ }^{3}$ (D) Ephraim Shapiro ${ }^{4}$
}

Received: 6 September 2021 / Revised: 29 October 2021 / Accepted: 2 November 2021 / Published online: 17 November 2021

(c) W. Montague Cobb-NMA Health Institute 2021

\begin{abstract}
COVID-19 has caused high morbidity and mortality in Israel but, as in other countries, not all groups were equally affected. Haredi Jews (often called ultra-Orthodox), a religious minority, were disproportionately harmed by the pandemic. This group has distinctive cultural, lifestyle, and demographic characteristics, which may be related to these higher COVID-19 rates and call for policies specifically adapted for this community. This paper describes in detail the steps the Israeli Ministry of Health $(\mathrm{MoH})$ took to try to improve the quality of care and prevent morbidity in the Haredi population through working in cooperation with the leadership and members of the Haredi community and strengthening mutual trust in order to increase adherence to government regulations and recommendations. This case study is based on the unique perspective of the two people who worked in the Israeli $\mathrm{MoH}$ and led the initiative as well as a review of relevant government documents and statistics. It discusses to what extent the initiative seemed to have been successful and what lessons can be learned not only for Haredim but for other religious and/or minority groups and closed communities in Israel and elsewhere.
\end{abstract}

Keywords Coronavirus $\cdot$ Health policy $\cdot$ Israel $\cdot$ Haredi $\cdot$ Minority groups

\section{Background}

Following the COVID-19 outbreak in late 2019, public health experts worldwide urged governments to implement restrictions in an effort to slow disease transmission, reduce morbidity and mortality, and prevent an overwhelming burden on healthcare systems [1-3]. Given the dynamic nature of the pandemic in Israel, as elsewhere (see Table 1), the decisions regarding restrictions and guidelines that aimed to

Hanni Schroeder

Hannischroeder1@gmail.com

Ronny Numa

ronny.numa@gmail.com

Ephraim Shapiro

eas97@caa.columbia.edu

1 Faculty of Medicine, The Hebrew University of Jerusalem, Jerusalem, Israel

2 Ministry of Health, Jerusalem, Israel

3 Israel National Haredi Corona Project Manager, Synrgai Inc, Tel Aviv, Israel

4 Department of Health Systems Management, Ariel University, Ariel, Israel reduce COVID-19 spreading required a fast pace of learning and rapid decision-making.

As with other countries, transmission rates were not equal among all sectors of Israel. Although in the past Haredi Jews (often called ultra-Orthodox) generally had better morbidity and mortality rates, for many but not all diseases, as compared to many other groups in Israel [4, 5], they suffered from disproportionately worse outcomes of COVID-19.

The spread of COVID-19 in Israel in March 2020 led to particularly high infection rates among the Haredi population $(26 \%)$, relative to their proportion in the population (12\%) [6]. Members of this group subsequently have had higher hospitalization and mortality rates compared with the general Israeli population (maximum daily mortality rate 0.07 per 10,000 persons compared to 0.02 and 0.01 in the Arab and general populations, respectively) [6-9].

COVID-19 is not the first outbreak of infectious diseases among Haredi Israelis in recent years. For example, there have been several outbreaks of measles and mumps that were disproportionately found among Haredi families [10-12]. Vaccine hesitancy and lifestyle, large families living in small apartments, and many communal activities have been thought to be important factors for this. Rates of fully vaccinated children in two Israeli Haredi communities were 
Table 1 Chronology of events

\begin{tabular}{ll}
\hline Date & Event \\
\hline February 27, 2020 & First wave begins: COVID-19 patient discovered in Israel \\
June 21, 2020 & Appointment of an official "Person of contact" in the MoH for the Haredi population \\
July 1, 2020 & Beginning of the "second wave" in Israel \\
July 24, 2020 & Establishment of "Magen Israel": the Israeli national program for COVID-19 \\
August 21, 2020 & Establishment of, the "Ultra-Orthodox Desk" (HD) within Magen Israel \\
December 20, 2020 & Beginning of the "second wave" in Israel \\
December 20, 2021 & Vaccination campaign launched \\
February 7, 2021 & Beginning of the "second wave" in Israel \\
\hline
\end{tabular}

found to be lower than in Israel overall [13] and there has been an overall lack of knowledge within the Haredi community about the importance of vaccines [14].

Haredim are considered the most traditional and stringently religious Jews. They are not a monolithic group and generally divided into subgroups, each with attributes that can also potentially affect COVID-19 transmission rates [15-17]. There are several distinctive characteristics, such as cultural norms/activities, information sources, and demographics that distinguish the Haredim from other Jewish communities and which may affect COVID-19 transmission rates and willingness to follow government recommendations. Haredim are insular, often living in isolation from other communities and following strict religious rules. They also are hesitant to adopt modern technology including the internet [6]. As a result of all of these, they may have had less access to accurate information about COVID-19 [18].

There are also demographic characteristics thought to be part of the explanation for the higher COVID-19 rates among Haredim. They have a high birth rate, with much larger than average families [6]. The annual growth rate among Haredim is more than double that of the overall growth rate in Israel, resulting in a younger population, with the median age among them less than half of the nonHaredi Jewish population in Israel (16 vs. 35 , respectively) [6]. These large families often live in crowded households, an important factor that likely led to the rapid spread of COVID-19 among Haredim.

Haredim also disproportionately live in crowded, urban areas, which can be related to faster rates of COVID-19 transmission [6]. The population density in the Haredi cities is 5.2 persons, compared to an average of 2.9 for non-Haredi Jewish households. The Haredi city of Bnei Brak, where there were especially high rates of infection [19], is the most densely populated city in Israel [6].

In addition to different lifestyle/demographic characteristics, there are other factors that may affect Haredi COVID-19 rates, in particular those having to do with trust in government and/or science. Lack of trust can be an important factor that negatively affects immunization rates in general [14, 20, 21]. Studies have shown that trust is a strong factor in the decision to take preventive actions, often even more than access to relevant information. Greater trust in the healthcare system is associated with greater likelihood of getting vaccinated $[13,21,22]$. This is particularly true among minority populations, who generally exhibit lower levels of trust in physicians and the healthcare system, and have significantly lower uptake rates of vaccines [21].

This lack of trust in government institutions and science is especially found among Haredim [23-25]. They place far greater trust in spiritual leaders, their rabbis, who lack medical training. The rabbis' influence extends beyond issues related to religious matters, but include everyday decisions including health care $[15,18,26]$. Following the decisions of religious leadership such as those called "Great Torah Sages" in regard to such matters is considered to be a supreme value in Haredi society [17].

Religious leaders play a significant role in shaping believers' perceptions in ways that affect health [27]. Religious leaders influence their followers' access to health-related information and they may affect their health-promoting behaviors [28]; this has been especially true among Israeli Haredim during the COVID-19 pandemic [18, 26, 29]. A survey of the Haredi community found a high level of confidence in rabbinic leadership, and large percentages of Haredim think it is necessary to include rabbis when setting COVID-19 policy [30].

There is also evidence that perception of government discrimination in its policies led to a lack of trust [18]. Haredi men and women are under the impression that the instructions by government authorities were unreliable since, according to them, they addressed only a portion of the population, and were not relevant for them. There were reports of senior Haredi rabbinical leaders interpreting government regulations as an excuse to shut down their religious institutions and undermine their way of life [31].

As a result of the higher transmission rates, the Israel Democracy Institute (IDI), a nongovernmental organization with expertise in the Haredi community, investigated and highlighted a number of the factors mentioned above [23], such as the lack of trust and cooperation between the Haredi community and government. In view of the 
unique characteristics of the Haredi community in Israel, it sought to detail the way the community was coping with the COVID-19 crisis and offered recommendations for improvement.

The IDI described the Haredi community's preparation for the COVID-19 pandemic and how the interface of the state authorities with the Haredi society differs from that with the general society. It proposed a number of steps to address the situation, including several to be spearheaded by the Israeli MoH: These included direct appeal to rabbinical leadership, collaborations with local governments/authorities, communication campaigns targeted to Haredim, and establishment of testing centers within Haredi cities.

In response to this report and internal reviews as well as other factors, the Israeli $\mathrm{MoH}$ undertook an initiative to try to reduce COVID-19 transmission, morbidity, and mortality in the Haredi population through increased collaboration and cooperation between the $\mathrm{MoH}$ and the Haredi community. In June 2020, the MoH appointed an official "person of contact" (POC) for the Haredi (ultra-Orthodox) minority group population, as part of the COVID-19 Command and Control center. Two months later, in August 2020, as part of the foundation of the Israeli national program for COVID-19 called "Magen Israel" ("Protector of Israel" in Hebrew), a special task force for the Haredi community was established. The "Haredi Desk" (HD) aim was to provide a customized and culturally sensitive response to the management of the COVID-19 outbreak for this group. It was headed by a retired Major General that, due to his previous successful experiences working on challenging and highly sensitive issues with this community, was acceptable to a consensus of the Haredi community's leadership.

To allow for a neutral approach that was not politically controversial within the Haredi community because of affiliation with any one sector of the community, the HD leadership was not Haredi. However, to increase the cooperation of the Haredim with the epidemiological investigations to identify those potentially exposed to the virus, representatives from the community were trained to perform the investigations.

This study examines the activities of the HD with regard to the Haredi community in Israel, a fast-growing minority.

\section{Study Objectives}

1. To describe the Israeli Ministry of Health's initiative to reduce morbidity and mortality in the Haredi sector.

2. To understand to what extent the initiative has been successful.

3. To explore the initiative's implications for other religious and/or minority groups in Israel and elsewhere.

\section{Design}

This study used the case method approach. Case studies can be a valuable method for health-related research, including to describe programs and evaluate interventions [32]. It is especially appropriate when contextual conditions are relevant to the phenomenon under study, as is the situation here when the distinctive nature of the Haredi community makes them an important target of study.

In order to avoid the common problem of too wide a scope for case studies, several authors have recommended placing boundaries on a case that can prevent this from occurring such as through limiting time, place, and activities [33-35]. We have therefore narrowed the boundaries of our case to examine Haredim in Israel during the period after the initial wave of COVID-19 and the specific $\mathrm{MoH}$ activities taken regarding this community. This type of binding of the case can help ensure that the study remains reasonable in scope [32].

This type of case study is used to describe an intervention or phenomenon and the real-life context in which it occurred [32]. However, as well as having a descriptive function, there is also an instrumental purpose. An instrumental case study involves the exploration of a particular case with a view to understanding or gaining insights about a phenomenon of interest and a thorough study of a particular bounded phenomena [36]. Our purpose is not only to describe but to analyze the relevance of the $\mathrm{MoH}$ initiative to improve the health of the Haredi community to other groups and settings by trying to gain insight and understanding a particular situation or phenomenon [35].

\section{Data and Analysis}

The case study presented is based on participant observation of the two $\mathrm{MoH}$ principal staff members responsible for planning, implementing, and overseeing the initiative: the MoH Director of the Policy Planning unit and the $\mathrm{MoH}$ Project Director of the Haredi community during the COVID-19 outbreak; they are two of the coauthors of this paper. The participant observation included weekly in-person and video conferences with representatives of the Haredi community, including the three major types of groups of Haredim, Hasidic Lithuanian, and Sephardic, followed by on-site visits to all the cities that are predominantly Haredi. The visits included tours of places with high relevance to the Haredi daily life and that their mode of operation was a core issue during the COVID-19 pandemic: sacred sites like the Western Wall, synagogues, educational institutions, event halls, community clinics, 
and COVID-19 testing sites. Meetings were held with key community leaders: mayors, leading rabbis, heads of educational systems, school principals, teachers, and relevant military officers involved in COVID-19 initiatives. The meetings enabled surge planning and ongoing guideline updates, while promoting compliance and sustainability. Quotes provided below are based on notes and communications with the authors who were participant-observers, and translated by an author who is bilingual.

This was supplemented by a review and thematic analysis of relevant internal documents such as planning guidelines and presentations. A review of the literature was also performed and relevant statistics and findings from the government and other research were presented to shed light on the extent of the program's success.

Data were combined in an attempt to understand the overall case, not only the various parts of the case, and the contributing factors that influenced the case. Analyses also focused on identifying implications for Haredim in the future as well as collaborations between government and sectarian, or even non-sectarian, groups in the future.

The study was approved by the ethics committee of Ariel University.

\section{Findings}

\section{Initiative Development}

The HD focused on three major objectives:

1. Formulating COVID-19 policy guideline tailored to specific population needs and strengthening mutual trust.

2. Reducing the spread of the virus in Haredi community by increasing COVID-19 PCR testing, establishing unique quarantine solutions, and achieving a high rate of vaccination.

3. Increasing adherence to the recommended preventive measures.

Early on, it was clear to the Haredi Desk that for it to succeed in making a sustainable reduction in the COVID19 outbreak, it had to work in close collaboration with the Haredi community. As a team that consisted of a public health specialist and a retired military officer who were used to working closely with the community, the phrase "the brains are in the field (community)" became a common expression. The intention was not only to listen to the community, but to assimilate the substantive changes in policy decisions in accordance with feedback received. The HD subsequently updated the community about the changes made to revalidate and modify if needed. See Table 1 for a chronology of events and Table 2 for an overview of steps taken to address impediments to achieving MoH goals.

In order to stay updated about the local morbidity rates and the number of COVID-19 PCR testing and to address various municipality needs, daily phone calls were made to the mayor's offices and the local commanders in charge. Periodic in-person consultations were conducted in every Haredi municipality. In these visits, a member of the HD not only met with the city's senior management to fine-tune the policy outlines and guidelines to match the reality in the "field," but he or she also visited and met with representatives of a variety of religious educational institutions, synagogues, and HMOs. It is important to note that the program was initially rolled out in the large Haredi city of Bnei Brak, which, as was mentioned above, was especially hard hit by COVID-19. After it generated success and important lessons, the program was implemented in Hared cities nationwide.

To ensure that the Haredi municipalities were up-to-date with the frequently updated guidelines, timely updates of current COVID-19 regulations were delivered from the HD via a WhatsApp group of Haredi municipality representatives. "The guidelines are finally starting to get to the field" was the response of one of these representatives. To promote accurate policy decisions and guidelines and enable continuous contact and collaborations of the Haredi communities with the different stakeholders, a weekly status meeting took place with representatives of the municipalities, military, police, public relations office, Internal Security Ministry, Education Ministry, Haredi private education networks, Association of Synagogues, and others. In the meetings, the HD provided updated figures regarding COVID-19 morbidity rates, at the national and municipal levels, presented policy guidelines, and validated their applicability and sustainability with the participants. The municipality's representatives brought up obstacles and solutions to current challenges, presented actions taken to reduce the COVID-19 spread within the community, and provided updated morbidity and PCR testing figures for the city. The reactions from the representatives were very positive. The following are some written responses from representatives who attended the meetings: "Thank you, thank you for the cooperation"; "I really enjoyed your professionalism and listening yesterday!!!”; "We highly appreciate it!!!”; "Good job, well done, for listening and being able to accommodate changes!".

Additionally, extensive measures were taken to understand the unique complexity of the different customs and the diversity of every subpopulation in the Haredi community. These included in-depth research of professional literature and periodic consultations with leading researchers and key community and government figures. To give a sense of the extent to which detailed planning was performed, we will highlight two important areas: education and vaccination. 
Table 2 Overview of impediments to minimizing COVID-19 spreading in the Haredi population, population groups particularly affected, and key responses

Impediments

Logistical impediments

Lack of ongoing communication and mutual updates by the government with the Haredi community

Difficulty in reaching PCR and vaccination sites

Vaccination and PCR testing adherence

Inability to quarantine due to crowded households and poverty and food insecurity

Perceptual/behavioral impediments

Lack of adherence to the required guidelines

Educational challenges

Limited trust in authorities

Lack of knowledge regarding the required guidelines

Challenges related to religious lifestyle
Steps taken to address impediments

Establishment of a centralized government emergency management department for COVID-19 in the Haredi community

Daily phone calls to the mayor's office and the local commander in charge, and periodic visits to every Haredi municipality

Timely updates about the new published COVID-19 regulations were delivered from the HD via a WhatsApp group of Haredi municipality representatives

Mobile units and pop-up vaccination and PCR testing clinics in local community centers and even in city hall

Distribution of "prizes" to people who get vaccinated or get tested

Delivery of welfare-related activities tailored to the Haredi family's needs (food baskets, games, books, and grocery shopping) to quarantined or sick families

Transfer of COVID-19 positive patients to special recovery hotels that were culturally adapted for things like kosher catered food and holiday necessities

Collaborative writing of COVID-19 policy tailored guidelines, with representatives of the Haredi population, that take into account their specific needs and strengthen mutual trust

Enabling reopening of schools while enhancing specific guidelines that reduce risk of exposure and infection

Increased PCR testing of staff, mask-wearing, and physical distancing among both students and staff were instituted; shortening the school day and learning in shifts, outdoor learning, and/or integrated distance learning by phone were implemented when feasible and warranted Daily monitoring of staff and student and rapid sampling of the entire class capsule when needed or closure of educational institutions with high morbidity rates

Collaborating with community and spiritual leaders/rabbis and physicians Collaborations and empowerment of local governments/authorities

Targeted campaigns about vaccination and guidelines culturally adapted and targeted to the Haredi population

Specific guidelines (plans) related to detailed day-to-day Haredi life were written, including places or events with great religious significance such as synagogue attendance, visiting the Western Wall, holidays, and ritual baths. Approved guidelines were integrated into government guidelines and laws

\section{Education Initiative}

Schools and educational frameworks can be a potential source of COVID-19 spread and illness in the community. In Israel, as in many other countries, schools were closed for certain periods during the COVID-19 outbreak. Because education is a central value in the Haredi world, finding appropriate solutions and guidelines for keeping the education system open while minimizing COVID-19 transmission risk was a main objective of the daily work of the HD. As the two of the most highly respected Haredi rabbis stated, "[If no solution is found for opening the education system] There will be a civil war over education," meaning they are willing to give their lives over the continuity of the children's holy studies. For parts of the Haredi population, it is unacceptable to use the internet, and therefore, it was not possible to hold classes remotely with media like Zoom, as in the general population.

The HD worked meticulously, to provide an appropriate, comprehensive, and professional response to the issue. First, it studied in depth the subtleties and differences between the public and Haredi education systems; the classes for different age divisions; various institutions for boys and girls; and the specific ownership and regulators. Secondly, the HD worked closely with the relevant parties, including regular meetings with the Ministry of Education representatives, 
directors of the education department of the Haredi authorities, the independent education networks, heads of yeshivas, leading rabbis, the education desk in "Magen Israel," and others to write appropriate guidelines.

At the meetings, specific guidelines for each kind of institution were presented to enable the reopening of the education systems in the Haredi sector, in accordance with national policy. As part of the assessment, tours were conducted in Haredi institutions in a number of cities to get to know the infrastructure and conduct brainstorming sessions on possible solutions to address the main risk factors for morbidity in the education system such as student density or non-adherence to government guidelines. Specific guidelines were written for every type of religious institution with solutions adapted to each setting, which were met with very positive responses. The following are some responses from the representatives that attended the meetings: "Excellent discussion today! The important voices were heard!"; "Hope you will be able to conduct a significant portion of the recommendations!"; "I would like to thank you from the bottom of my heart for the professional management of the meeting held at the COVID headquarters, regarding the assessments of the reopening of the Haredi education system. May your reward for your actions be in stopping the plague"; and "These guidelines enable order."

\section{Vaccination Initiative}

Before the vaccines were approved by the $\mathrm{MoH}$, the HD utilized the already well-established connections it had created from the collaborative work with the Haredi community throughout the second and third waves to promote initiatives that would increase willingness to be vaccinated. The desk's work focused on three main objectives: advocacy actions that focused on the safety and importance of vaccination in the community; accessibility of vaccination clinics and hubs; and daily monitoring of the vaccination rates in the community.

Advocacy actions included "behind the scenes" meetings with influential rabbis on matters related to health so as to enlist the support of leading rabbis from different Haredi groups to the vaccination campaign, and encouraging the rabbis to write public letters declaring their support for vaccination. The Archimedean point was reaching an agreement with one of the most influential rabbis in matters related to health, to advocate for vaccination, set a personal example, and agree to use a photo of him getting vaccinated for the pro-vaccination campaign. His agreement to help and convince other rabbis to support the vaccine campaign in the same way was a key factor for promoting vaccination in the Haredi community. Here are some selection from letters that were written to the community by leading rabbis: "Anyone who is authorized to be vaccinated should do so. We pray that this will bring forward healing"; "I hereby come to encourage and strengthen the Haredim to keep God's Mitzvah [order] of 'save your souls' and get vaccinated against the corona virus." Leading rabbis stated in their weekly talk to the community: "You must get vaccinated. Don't be afraid that it will hurt the body."

When questions arose regarding the possible side effects of the vaccine on fertility, medical experts were recruited to provide information to Haredi community leaders regarding vaccine safety before and during pregnancy. Finally, when the vaccines were approved and the vaccine campaign started in Israel, Haredi mayors, rabbis, and community leaders set a personal example and were vaccinated early and publicly. The MoH ran a campaign targeted specifically for the Haredi community that included community billboard posters, messages in magazines and newspapers, flyers, and phone messages. The messages included rabbinical statements and biblical verses that support vaccination.

Because the Haredi population is characterized by a relatively low rate of vehicle ownership [6], and public transportation was reduced during the COVID epidemic, pop-up clinics were opened in local community centers and even in city halls. Vaccines were administered throughout the day until $10 \mathrm{pm}$. Certain cities had local initiatives such as special vaccination "parties" that included vaccinating all night and distribution of free pizza or cholent (a stew popular among Haredim). Steps were also taken to ensure that those homebound or people with a disability were able to get to the vaccination clinics. Vaccination hubs were also brought to religious study halls to facilitate vaccination of the students and the staff. An example of a poster that was made by a Haredi municipality to encourage vaccinations states "Observe the great rabbi's guidance to get vaccinated. Vaccines available with no need in coordination and no waiting time. Just show up and get vaccinated. Free cholent or pizza for people that get vaccinated."

\section{Initiative Results}

The HD activity has improved the effectiveness of COVID19 prevention and care for the Haredi population on several levels. Accessibility of tests increased in the Haredi cities, via a combination of numerous methods including mobile vaccination clinics, PCR testing in local community centers and religious institutions, and a special motorcycle unit that performed PCR tests in quarantined houses. As one of the governmental leaders of a major Haredi municipality said, "we were in third place [in the daily COVID-19 city ranking of highest case rates] and we are now 16th on the list! It's amazing."

The creative all-night vaccination festivals that included free food successfully encouraged vaccination. According 
to the MoH database, the number of PCR tests for Haredim increased from 104 tests per 10,000 people in the first wave to a rate of 593 and 979 tests per 10,000 people in the second and third waves, respectively, which brought PCR testing rates among Haredim (5131 PCR test per 10,000 persons) to levels even higher than the general population (4571 per 10,000 persons) and other minority groups in Israel (e.g., Arabs with 2130 tests per 10,000 persons). Welfare-related activities tailored to the Haredi family's needs included food baskets, games, books and grocery shopping, and delivery for quarantined or sick families. There was also an option for Haredi patients to spend their recovery time in designated recovery hotels that were culturally adapted, for example, to meet strict religious dietary law requirements and allow for Sabbath and holiday necessities.

Men and women from within the Haredi community were recruited to facilitate the epidemiological investigations needed to help contain the virus spread. This increased trust and resulted in more accurate results. However, leadership was maintained by the HD to eliminate conflicts among the various groups within the Haredi sector.

Greater cooperation, fine-tuning promotional material, and involvement of key spiritual leaders increased compliance with important behaviors like mask-wearing and physical distancing. Crafting detailed guidelines together with the community leaders resulted in more public trust. The HD provided tens of guidelines related to daily life in real time, dealing with religiously significant topics like synagogue attendance, use of ritual baths, and visits to holy sites. Improved guidelines were incorporated into government guidelines and laws.

Adherence to government regulations, increased PCR testing of staff, and mask-wearing and physical distancing among both students and staff were instituted. Shortening the school day and having students study in separate sessions helped reduce risk of exposure and infection. Outdoor learning and/or integrated distance learning by phone was implemented when feasible.

There was also daily monitoring of staff and students and rapid COVID-19 sampling of the entire classroom unit when needed. Schools were closed only when morbidity rates were high, subject to the decision of the MoH District Health Bureau. The education initiative was closely monitored, with daily/weekly reports to the local authority.

Likewise, the HD closely monitored the progress of the vaccination process in the Haredi cities and offered solutions when difficulties arose. Daily meetings were held with city's representatives and the health plans (HMOs) that were in charge of delivering the vaccinations. At bi-weekly visits to the cities, often together with the MoH COVID-19 project director, further collaborative solutions with the community were suggested and implemented. Advocacy with rabbis and opinion shapers resulted in high immunization rates in some cities (e.g., over 95\% among those aged 60 in a number of Haredi cities(. The result was a total vaccination rate similar to the general population ( $71 \%$ among persons over 15 that have not been diagnosed with COVID-19) (MoH database).

In keeping with the above, it is also important to note that not all the efforts of the HD were fruitful. Over the course of the initiative, there were also many challenges. For example, there was a lack of adherence to the required guidelines among certain Haredi population sectors, who persisted in holding crowded gatherings such as weddings and funerals. In addition, there were difficulties in maintaining a positive working relationship with some Haredim while ongoing negative descriptions of the lapses in adherence appeared in the media and tarnished the community's image. This feeling of discriminatory treatment was exacerbated by the perception of less critical and even sympathetic reporting of mass political demonstrations by non-Haredim. This made it difficult to convince the Haredim to discontinue educational and religious activities.

It is important to note that although steps were taken to defuse opposition, as described above, there are also political forces that influenced the extent of the Haredi community's opposition to the initiative. These forces could help advance or undermine the efforts to promote adherence to the required guidelines.

Despite these obstacles, the work of the $\mathrm{MoH}$ with the Haredi sector seems to have been successful overall and has strengthened the population's trust in the health system in general and in the ministry in particular. In the concluding meeting with the Haredi municipalities, the mayors of the cities declared that the HD was a unique bridge that enabled them for the first time to communicate to top authorities the specific needs of their population. They credited the work with helping to promote solutions for reducing morbidity and mortality and promoting welfare and education for the community during the COVID-19 pandemic.

In view of this success and a better understanding of the existing population's needs, it was evident that a dedicated plan for this population's health should be established. For the first time, a MoH strategic health plan for the Haredi population was developed that included even non-COVID19-related health matters such as routine treatment of diabetes, obesity, vaccines, and pediatric injuries.

The following are a few quotes from key leaders in the Haredi community: "In the beginning of the second wave when the government transferred COVID patients to hotels, there were trust issues due to Kashrut [strict religious dietary law requirements]... these issues were dealt with via mutual communication of the communities with the government representatives... the successful experience restored the mutual trust"; "The COVID-19 outbreak was an opportunity to re-bridge gaps within the Israeli society"; "We thank the HD for being a "bridge" between us and the Ministry 
of Health. The activity contributed to lowering the "wall" between the Haredi community and the government."

\section{Discussion}

The case study presented in this paper describes an important collaboration between government and Haredi Jews in Israel, a religious minority with distinctive characteristics that may be related to the impact of COVID-19. It makes a valuable contribution in complementing and building upon prior literature, from a unique and detailed vantage point of the government's initiative. Described are efforts to disrupt the virus' infection chains and reduce its spread and, later, to increase vaccination in Haredi communities. There is evidence of government and religious communal institutions working together or what is sometimes called faith-based initiatives [37]. However, few of the studies have dealt with Jewish groups and even fewer about Haredim.

This study's findings about the successes of the government initiatives, albeit with challenges and limitations, are consistent with the limited number of studies and reports about Haredim in Israel during the COVID-19 period [9, 38]. An in-depth study of one Israel city [26] described how health and government authority figures employed methods to change the Haredi community health behaviors during COVID-19. It concluded that the healthcare crisis among the Haredi community in Beit Shemesh led to some success in increased compliance, thus lowering morbidity rates. However, the authors noted that not establishing strong respect and rapport hindered the process. A recent study about vaccination in Israel mentioned the government's collaboration with the Haredi community in the context of a number of steps the government took to increase vaccination [38]. The case study presented in this paper complements these earlier studies and expands and deepens our understanding about the government's initiative with Haredim during COVID-19 and suggests how trust between them can be increased.

The topic of Haredim and COVID-19 is one that has received much coverage, often critical, in both the international popular and academic literature [39-41]. Some have accused the Haredim of receiving preferential treatment and/or flouting government regulations. This is certainly a more complex and nuanced subject than its usual presentation. This paper can play a role in increasing awareness and understanding that there have been significant efforts by both the Haredi community and the government for improved, if still imperfect, cooperation. This topic is especially important because of the ongoing threat of new variants which may increase the spread of the virus as the COVID-19 and continues to negatively impact both young and old. The findings from this study demonstrate the positive potential of dialog and collaboration to provide tools for long-term as well as short-term solutions to health challenges.

This paper also has important policy implications for Haredim in Israel and other countries both in continuing to try to reduce morbidity during the pandemic and increasing trust [18, 25, 42], and in future health crises. Others have noted the need for culturally sensitive approaches in reducing COVD-19 among Haredim [23, 41] and the initiative described attempted to do so in an intensive and methodical manner. The specific steps taken by the government have had a positive impact on Haredim in Israel and can have a positive impact for other religions and in other minority communities there as well [38]. In particular, the very detailed planning and implementation process and the many steps taken to build trust between the $\mathrm{MoH}$ and religious leaders are valuable examples for other government bodies working with insular communities.

We believe that this paper also helps shine a light on the importance of cultural competence in the public health sphere in general, and particularly in the challenging period since the coronavirus pandemic began, with lessons to be learned for other communities. It is noteworthy that the initiative was supported and not undermined by the members of the Haredi community's leadership. The health officials' sincere listening and close attention to voices within the community created a reciprocal respect which removed perception of possible prejudice or ill-intent.

This paper can also be of value for other religious groups both in Israel and closed societies elsewhere where issue of trust is endemic, and lessons can be learned from this case study $[8,43,44]$. Every country has vulnerable populations that require special attention from policymakers, especially during a pandemic, when cultural attitudes and lack of healthcare access are life-endangering. In order to carry out a comprehensive national intervention plan, policymakers should be sensitive to the needs and lifestyles of these groups, while taking into account structural and cultural gaps while developing appropriate policies $[8,9]$.

\section{Limitations/Additional Research}

There were a number of limitations to this study. While some evidence was presented supporting the findings that the initiative had a generally positive impact, more quantitative/epidemiological data would be helpful to better support the conclusions. While this was beyond the scope of this study, we hope such additional research will be performed in the future.

This was a single case study of a particular country and religious group so while we do think there are lessons to be learned for other groups, the extent of generalizability of the findings to other groups or other pandemics is unclear. 
As mentioned above, the Haredim are not a monolithic group and there may be subgroups such as the Hasidic, Lithuanian, and Sephardic segments. While beyond the scope of our study, it could beneficial for future research to examine these groups individually.

The vaccination campaign is ongoing and the impact of COVID-19 is still unfolding. Therefore, there may be additional lessons to be learned that are not yet clear from the current study.

\section{Conclusion}

COVID-19 has proven to be a major threat to the health and well-being of the populations of many countries, including Israel. It has not affected all groups in the same manner. Haredi Jews have both a distinctive lifestyle that may increase their risk and their beliefs may also make it less likely that they adhere to government recommendations. We present a case study describing the Israeli Ministry of Health's intensive efforts to build bridges with the Haredi community and reduce COVID-19-related morbidity and mortality. Such an initiative has potentially important implications for other groups where focused collaborations between the government and other closed sectors of society may be challenging.

Acknowledgements We thank Ms. Barbara Sofer from Hadassah Woman's Zionist Organization of America, for her professional input and helpful discussions that greatly contributed to the paper.

Author Contributions All authors contributed to the study conception and design. Material preparation, data collection, and analysis were performed by HS with assistance from ES. The views expressed do not necessarily represent those of the organizations in which the authors work or worked. The first draft of the manuscript was written by ES and HS. All authors read and approved the final manuscript.

\section{Declarations}

Ethics Approval This study was approved by the Ariel University Ethics Committee (approval number AU-HEA-ES-20210804).

Conflict of Interest The authors declare no competing interests.

\section{References}

1. Gilardino RE. Does "Flattening the curve" affect critical care services delivery for COVID-19? A global health perspective. Int J Health Policy Manag. Kerman University of Medical Sciences; 2020;9:503-7.

2. Kissler S, Tedijanto C, Lipsitch M, Grad YH. Social distancing strategies for curbing the COVID-19 epidemic. medRxiv. 2020;2020.03.22.20041079.
3. Kraemer MUG, Yang C-H, Gutierrez B, Wu C-H, Klein $\mathrm{B}$, Pigott DM, et al. The effect of human mobility and control measures on the COVID-19 epidemic in China. Science. 2020;368:493.

4. Brammli-Greenberg S, Glazer J, Shapiro E. The inverse U-shaped religion-health connection among Israeli Jews. J Relig Health. 2018;57:738-50.

5. Ronit Pinchas-Mizrachi, Zalcman BG, Shapiro E. Differences in mortality rates between Haredi and non-Haredi Jews in Israel in the context of social characteristics. J Sci Study Relig. Hoboken: Blackwell Publishing Ltd.; 2021;60:274-90.

6. Malach G, Cahaner L. Statistical report on ultra-Orthodox society in Israel [Internet]. Israel Democracy Institute; 2020. Available from: https://en.idi.org.il/haredi/2020/?chapter $=34272$. Accessed 5 Sept 2021

7. Averbach E, Peretz G, Eidelman L, Avni S, Greenbaum-Ari-

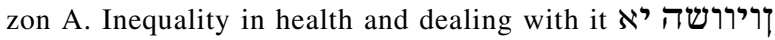
ומע תודדומתהר תואירבב [Internet]. Israel Ministry of Health Economic Strategic Planning Administration; 2020 p. 190. Available from: https://www.gov.il/BlobFolder/reports/ health-inequality-2020/he/publications_inequality_inequality2020.pdf. Accessed 5 Sept 2021

8. Taragin-Zeller L, Rozenblum Y, Baram-Tsabari A. Public engagement with science among religious minorities: lessons from COVID-19. Sci Commun. 2020;42:643-78.

9. Waitzberg R, Davidovitch N, Leibner G, Penn N, BrammliGreenberg S. Israel's response to the COVID-19 pandemic: tailoring measures for vulnerable cultural minority populations. Int J Equity Health. 2020;19:71.

10. Stein-Zamir C, Zentner G, Abramson N, Shoob H, Aboudy Y, Shulman L, et al. Measles outbreaks affecting children in Jewish ultra-orthodox communities in Jerusalem. Epidemiol Infect. 2008;136:207-14.

11. Anis E, Grotto I, Moerman L, Warshavsky B, Slater PE, Lev B. Mumps outbreak in Israel's highly vaccinated society: are two doses enough? Epidemiol Infect. 2012;140:439-46.

12. Stein-Zamir C, Levine $H$. The measles outbreak in Israel in 2018-19: lessons for COVID-19 pandemic. Hum Vaccines Immunother. 2021;17:2085-9.

13. Muhsen K, Abed El-Hai R, Amit-Aharon A, Nehama H, Gondia $\mathrm{M}$, Davidovitch N, et al. Risk factors of underutilization of childhood immunizations in ultraorthodox Jewish communities in Israel despite high access to health care services. Vaccine Kidlington: Elsevier Limited. 2012;30:2109-15.

14. Stein Zamir C, Israeli A. Knowledge, Attitudes and perceptions about routine childhood vaccinations among Jewish ultraOrthodox mothers residing in communities with low vaccination coverage in the Jerusalem district. Matern Child Health J. New York: Springer Nature B.V. 2017;21:1010-7.

15. Friedman M. Ultra-Orthodox society: sources trends and processes. Jerusalem: Jerusalem Institute for Israel Studies; 1991.

16. Leon N. Soft ultra-Orthodoxy: religious renewal in oriental Jewry in Israel. Jerusalem: Yad Izhak Ben-Zvi; 2010.

17. Brown B. The Haredim. A guide to their beliefs and sectors. Israel Democracy Institute; 2017.

18. Zalcberg S, Block SZ. COVID-19 amongst the ultra-Orthodox population in Israel: an inside look into the causes of the high morbidity rates. Contemp Jew [Internet]. 2021 [cited 2021 Aug 18]; Available from: https://doi.org/10.1007/ s12397-021-09368-0

19. Schattner A, Klepfish A. Orthodox Judaism as a risk factor of COVID-19 in Israel. Am J Med Sci. 2020;360:304.

20. Keshet Y, Popper-Giveon A. "I took the trouble to make inquiries, so I refuse to accept your instructions": religious authority and vaccine hesitancy among ultra-Orthodox Jewish mothers in Israel. J Relig Health. 2021;60:1992-2006. 
21. Freimuth VS, Jamison AM, An J, Hancock GR, Quinn SC. Determinants of trust in the flu vaccine for African Americans and Whites. Soc Sci Med. 2017;193:70-9.

22. Yaqub O, Castle-Clarke S, Sevdalis N, Chataway J. Attitudes to vaccination: a critical review. Soc Sci Med. 2014;112:1-11.

23. Malchi A, Malach G, Friedman S. The ultra-Orthodox sector's response to the corona plague and policy recommendations I 2020 [Internet]. Israel Democracy Institute; 2020 Mar. Available from: Charedim During Corona and Public Policy.pdf

24. Trencher M. COVID-19 attitudes and vaccine hesitancy in the U.S. Orthodox Jewish community: views among the Chasidish, Yeshivish, and Modern Orthodox segments. West Hartford, Connecticut: Nishma Research; 2021.

25. Carmody ER, Zander D, Klein EJ, Mulligan MJ, Caplan AL. Knowledge and attitudes toward COVID-19 and vaccines among a New York Haredi-Orthodox Jewish community. J Community Health [Internet]. 2021 [cited 2021 May 25]; Available from: https://doi.org/10.1007/s10900-021-00995-0

26. Romem A, Pinchas-Mizrachi R, Zalcman BG. Utilizing the ACCESS model to understand communication with the ultraorthodox community in Beit Shemesh during the first wave of COVID-19. J Transcult Nurs. 2021;104365962110095.

27. Shapiro E. A protective canopy: religious and social capital as elements of a theory of religion and health. J Relig Health [Internet]. 2021 [cited 2021 Aug 23]; Available from: https://doi.org/ 10.1007/s10943-021-01207-8

28. Peles C, Rudolf M, Weingarten M, Bentwich ME. What can be learned from health-related tensions and disparities in ultraOrthodox Jewish families? J Relig Health. 2018;57:1133-45.

29. Frei-Landau R. "When the going gets tough, the tough get-creative": Israeli Jewish religious leaders find religiously innovative ways to preserve community members' sense of belonging and resilience during the COVID-19 pandemic. Psychol Trauma Theory Res Pract Policy. 2020;12:S258-60.

30. Hermann T. Haredim trust rabbis more than the health ministry on COVID-19. Isr Democr Inst. 2020;5.

31. Rabbi Kanievsky orders Haredi boys schools to reopen, then rescinds his decision. Times Isr [Internet]. Available from: https:// www.timesofisrael.com/rabbi-kanievsky-suffering-from-covidrevokes-order-to-open-haredi-boys-schools/. Accessed 5 Sept 2021

32. Baxter P, Jack S. Qualitative case study methodology: study design and implementation for novice researchers. Qual Rep [Internet]. 2015 [cited 2021 Aug 22]; Available from: https:// nsuworks.nova.edu/tqr/vol13/iss4/2/
33. Stake R. Stake, R. E. (). The art of case study research. Thousand Oaks, CA: Sage Publications; 1995.

34. Creswell J. Research design: qualitative, quantitative, and mixed methods approaches. 3rd ed. Thousand Oaks, CA: Sage Publications; 2009.

35. Yin R. Case study research: design and methods. 3rd ed. Thousand Oaks, CA: Sage Publications; 2003.

36. Luck L, Jackson D, Usher K. Case study: a bridge across the paradigms. Nurs Inq. Oxford: Wiley Subscription Services, Inc. 2006;13:103-9.

37. Dilulio J. Godly Republic A Centrist Blueprint for America's Faith-Based Future. Oakland, California.: University of California Press; 2007.

38. Rosen B, Waitzberg R, Israeli A. Israel's rapid rollout of vaccinations for COVID-19. Isr J Health Policy Res. 2021;10:6.

39. Gilman SL. Placing the blame for COVID-19 in and on ultraOrthodox communities. Mod Jud - J Jew Ideas Exp. 2021;41:1-30.

40. Estrin D. Israel faces challenges in fighting coronavirus in ultraOrthodox communities. npr.org [Internet]. 2020 Apr 1; Available from: https://www.npr.org/2020/04/01/825260941/israel-faceschallenges-in-fighting-coronavirus-in-ultra-orthodox-commu nities. Accessed 5 Sept 2021

41. Saban M, Myers V, Peretz G, Avni S, Luxenburg O, Wilf-Miron R. Changes in COVID-19 morbidity in an ethnic minority between first and second pandemic waves [Internet]. In Review; 2021 Jan. Available from: https://www.researchsquare.com/article/rs146002/v1. Accessed 5 Sept 2021

42. Vanhamel J, Meudec M, Van Landeghem E, Ronse M, Gryseels $\mathrm{C}$, Reyniers T, et al. Understanding how communities respond to COVID-19: experiences from the Orthodox Jewish communities of Antwerp city. Int J Equity Health. 2021;20:78.

43. Bramadat P, Berger BL, MacDonald N. COVID -19 Vaccine, religion, trust and vaccine acceptance. R Soc Can. 2021;3.

44. Ayalon L. Trust and compliance with COVID-19 preventive behaviors during the pandemic. Int J Environ Res Public Health [Internet]. 2021;18. Available from: https://www.mdpi.com/16604601/18/5/2643. Accessed 5 Sept 2021

Publisher's Note Springer Nature remains neutral with regard to jurisdictional claims in published maps and institutional affiliations. 